\title{
Financial Analysis of Jatropha Plantations in the context of Nepal
}

\author{
Narayan Prasad Adhikari, Michael Wegstein
}

Alternative Energy Promotion Centre (AEPC)

Email: narayan.adhikari@aepc.gov.np; michael.wegstein@gmx.de

\begin{abstract}
In general two scenarios for Jatropha plantations are considered to be realistic for Nepal. The first scenario concentrates on the Terai region. In this area large-scale plantations seem to be possible for example in locations formerly subjected to flooding. The plantations can be set up within a professional context - meaning to provide the necessary inputs (fertilizer, labour) for maximising yields. Using this sort of wasteland Jatropha can be used to produce straight vegetable oil (SVO) for the direct use in water pumps or modified engines or if the yield exceeds the demand for SVO, with establishing transesterification-units the SVO can be transformed into biodiesel. With water pumps crops can be increased from one yield per year up to three yields per year with irrigation.

The second scenario concentrates on the hill region. In this context Jatropha is considered as being part of poverty alleviation strategies. Per household 500 plants could be planted as a fence, along roads, against erosion or around the leasehold forestry areas. In this scenario no plant care besides some cutting and weeding is assumed. Accordingly the yield is expected to be lower than in the first scenario. For hill areas the SVO will mainly find application for lightning or running processing mills, pumps, generators or tractors. Replacing Kerosene and Diesel in modified engines and lamps will be the best application for the hill areas. Transforming SVO into biodiesel is economically not viable and efficient as the analysis will show.
\end{abstract}

Key Words: Biofuel, Jatropha, financial analysis, renewable energies, transesterification, Jatropha plantation, Biodiesel, Cash flow analysis

\section{Introduction}

Speaking about biofuels, Jatropha is considered by many as kind of a magic plant to solve poverty, climate change and other problems. In the recent years plantations have been set up all over the world by development co operations, NGOs and even large business companies to produce biodiesel out of the seeds. Biodiesel is considered to be one reasonable and potential option for replacing normal diesel and to contribute essentially to reductions in $\mathrm{CO} 2$.

The expectations and euphoria is enormous, though the research and knowledge of Jatropha was and is still in its childhood stages. Jatropha has up to now considered as a wild - nondomesticated - plant with the consequence that thorough projections of the yield lack a scientific basis and therefore any projection has a strong character of hoping and guessing. This is also reflected in the yield reports of some plantations. Additionally the numbers have to be interpreted carefully because the yield itself is influenced by several parameters. Overall the difficulty in yield-prediction is the major constraint for any financial analysis of Jatropha plantations. 
The government of Nepal has recently launched a program to promote and support Jatropha plantations throughout the country. The program aims to reduce the import of normal diesel by biodiesel and also by that reduce the dependency on foreign resources. Within this framework the study analysis the different financial aspects of production of seeds, Jatropha oil and biodiesel to find out under what conditions Jatropha cultivation could be a successful and promising option for Nepal.

\section{Objective}

This study tries to find out under which conditions Jatropha plantations are financially viable. It analyses the value added on the different levels of plantation, extraction and transesterification and finally compares the price of one litre straight vegetable oil (plant oil) and one litre biodiesel to the current price of normal diesel.

This study also tries to give some ideas of how further promotion and support of Jatropha could be formulated and what its implications might be.

\section{Activities and Analysis}

In the first step a thorough analysis of the existing literature of Jatropha has been undertaken. With this understanding the relevant parameters for a financial analysis have been defined. In a field visit these parameters have been proofed in several interviews with Jatropha experts in Nepal. Further relevant input information has been collected from plantations and manufacturers in India. Finally the data was put together and analysed in a financial model.

\section{Findings}

\subsection{Jatropha in Terai}

\subsubsection{Investment}

For the initial investment each single step for setting up the plantation has been considered. The seedlings will be planted in $2 \times 2$ meters, in total 2500 plants per hectare. 91 man-days are required for the whole process if the ground is difficult to handle. If the soil is sandy and without stones the site preparation and alignment will require less labour.

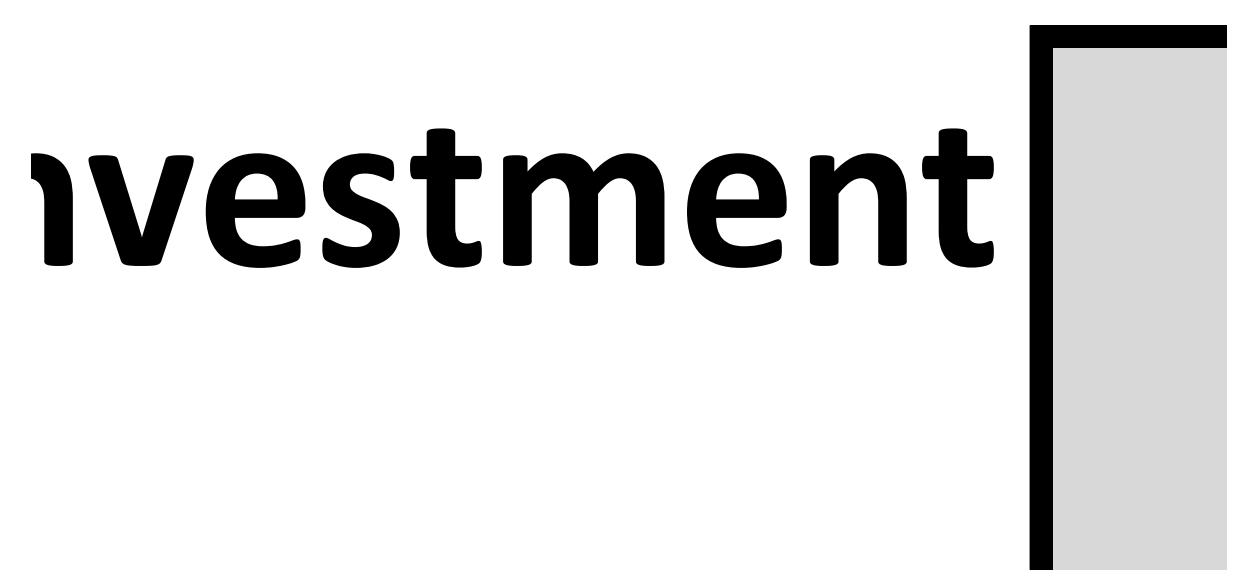

Table 1: Investment costs of 1 ha plantation in Terai 
The work for preparing the ground can be done during the dry season, so that the plantation of the seedlings is possible with the beginning of the monsoon rainfalls. So the major work does not coincide with the period of rice plantation. Right now no market price for seedlings could be found. Most of the seedlings have been sold for 5 Rs.

\subsubsection{Plantation}

Till now the projection of the yield is very difficult but crucial for the analysis. So far for Nepal no practical experience for plantations exists. Therefore for this study a worst case scenario has been considered with a yield of $2500 \mathrm{~kg}$ of dry seeds per hectare after 5 years and 3,000 kg after 10 years. The production price of one $\mathrm{kg}$ of dry seeds starts from Rs. 36 in the $2^{\text {nd }}$ year and decreases to Rs.12.3 in the $6^{\text {th }}$ year. The demand price is around Rs.15 (at this price Indian traders are willing to buy seeds in Nepal). The cash flow analysis shows that there is a small profit beginning with the $4^{\text {th }}$ year. But due to the high initial investment the net present value (NPV) is negative and the internal rate of return (IRR) is around $8.5 \%$. Under these conditions plantations are difficult to run efficiently and financially viable. A solution could lie in supporting the plantation e.g. in subsidising the initial investment by giving free seedlings as a subsidy. This reduces the initial investment by $28 \%$ and gives the farmer/ community an appropriate profit with NPV at 67,000 and IRR at $13.5 \%$.

\subsubsection{Extraction and use of the oil}

Two types of oil expellers with different capacities have been analysed: A small expeller with a capacity of $17,5 \mathrm{~kg}$ seeds $/ \mathrm{h}$ and a large expeller with $75 \mathrm{~kg}$ seeds $/ \mathrm{h}$. The analysis shows that the smaller expeller the higher the costs of the plant oil per litre. With a large expeller the costs for the expeller and labour are marginalised so that production costs nearly equal input costs of the seeds. The price of one litre of oil is for the large expeller Rs. 61 and for the small expeller Rs. 71.The required amount of seeds for one litre oil depends strongly on the oil content of the seeds but in average $4 \mathrm{~kg}$ of seeds give 1 litre of oil.

The use of Jatropha oil for running water pumps will improve the living conditions of the farmers in Terai in many regards. Being able to at least double the crop by irrigation farmers will increase their income. Additionally with Jatropha plantation and expelling there is a creation of value on village level. By selling seeds or crude oil that is not required for running water pumps communities are able to create additional income out of the Jatropha plantations. This overall will lead to an increase in economical activities and have a positive impact on the local economy.

\subsubsection{Transesterification}

The analysis shows, that with the two existing plants in Nepal biodiesel could be produced for Rs. 71 under the assumptions that the seeds are available at Rs. 15 per $\mathrm{kg}$ or the litre of SVO is produced under efficient conditions and is available for Rs. 61 . With a new plant biodiesel could be produced for Rs. 76/ litre under the same assumptions (Rs. 5 per liter for financial costs). Compared to the actual market price of normal diesel, biodiesel is not competitive as the litre of biodiesel costs right now (Oct. 2009) around Rs. 65. BUT sooner or later the price of normal diesel will rise again and thus make biodiesel-production competitive. 
Biodiesel has a great potential for farmers, communities and Nepal's economy as it can replace costly imports of normal diesel especially in remote areas. Biodiesel production generates addedvalue on the grass root level - in villages and rural areas. This enhances the local income level and could give valuable impulses for the local economy. Instead of cash outflow for diesel imports the money flows to the producers of Jatropha seeds, Jatropha oil and biodiesel.

\section{price of oil[}

Table 2: Cash flow of Biodiesel-unit with 1000 litre/day capacity

\subsection{Jatropha in hill areas}

\subsubsection{Plantation}

Generally a small-scale approach with 500 Jatropha plants per poor household in hill areas was analysed. This approach was taken from existing documents and strote ies of AEPC. The $\mathrm{p}$ ants can be established on wasteland provided by the gor m m explat ope planted as a hedge around leasehold forest areas, along roads or on eroded areas. Besides the initial investment the basic input consists mainly on labour so that no additional cash is required. The Cash flow analysis shows that including the initial investment the break eren point of this investment is reached after six years. The IRR is positive and NTh.5 on alsh he evel, the NPV is Rs. 11,000. Reducing the investment costs of $30 \%$ Rs. 30,000 for 15 years and a discount rate at $10 \%$. IRR then is calculated at $26.5 \%$. This reduction could for example be achieved by subsidising the seedlings and overall will have a positive effect of a significant increase of the household income.

\subsubsection{Extraction and use of oil}

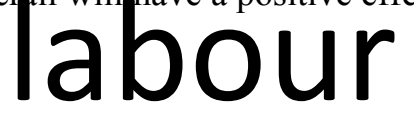

Extraction of the oil in the given context is assumed to be done by a manual expeller due to the lack of electricity in most of the rural areas and at lower q antities of seeds availabe. The costs

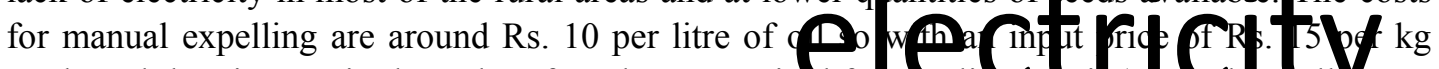
seeds and the given ratio that $5 \mathrm{~kg}$ of seeds are requirefor on the less efficient), the litre of oil costs around Rs. 85. This also shows that manual extraction is less efficient than electrical extraction. Though the SVO might not be competitive to kerosene or diesel in all places right now, this is just a matter of tim 20

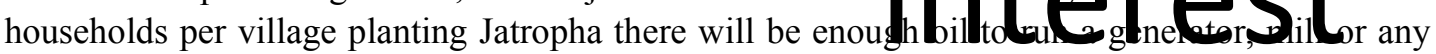
other kind of modified engine for 2-3 hours per day yearlong.

In general the use of Jatropha oil offers a broad range of applications on the village level.

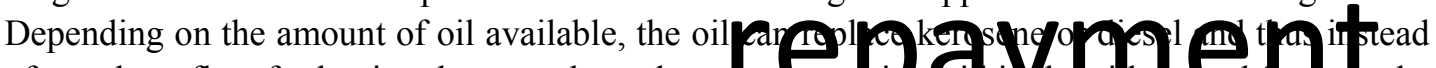

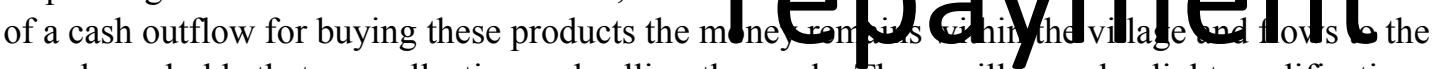
poor households that are collecting and selling the seeds. There will be only slight modifications for the engines necessary (if at all). If there is no use of kerosene or diesel so far within a village

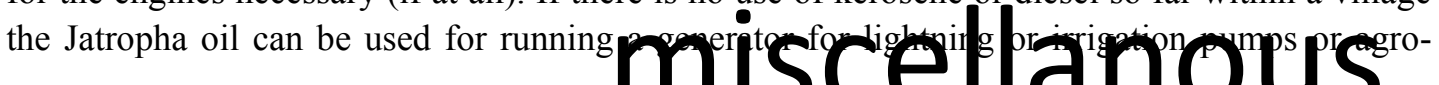


processing mills in average for 2-3 hours per day. This leads to a general improvement of the living conditions of the villagers in the hill areas. Production of biodiesel in remote areas is right now not recommendable. 


\section{Recommendations}

Promoting Jatropha plantations in Nepal has to be done very carefully because food production has highest priority before considering the cultivation of non-food-plants on any so called wastelands. To avoid any kind of conflict from the beginning wasteland suitable for Jatropha plantation should be officially declared by the local authorities with the support of GIS maps and local expertise in a participatory and transparent manner.

There is considerable further research required to improve the quality of the seedlings and thereby increase the yield and the oil content of the plants.

A clear policy is required to encourage the establishment of plantations and to promote the use and advantages of Jatropha on wasteland. Responsibilities, processes and policies have to be communicated to all stakeholders to have a basic understanding. Also co-ordination of the existing activities are strongly recommended to share experiences and knowledge and enhance and speed-up Jatropha plantation and processing.

Research and a pilot project should be carried out in the field of modifying engines running on diesel/ kerosene basis and further experience is needed in running water pumps based on plant oil.

\section{REFERENCES}

[1] Alternative Energy Promotion Centre, Manual on Jatropha Plantations”, year 2009.

[2] Bionepal, GoN/ Department of Forest, "Draft report on Economic Feasibility of Jatropha in LFLP Area, Kathmandu, Jan. 2008.

[3] FACT Foundation publication, “Jatropha Handbook”, 2 ${ }^{\text {nd }}$ edition, June 2009.

[4] FACT Foundation, "Position Paper on Jatropha curcas”, June 2007.

[5] Ferchau Erik, "Equipment for decentralised cold pressing of oil seeds", Folkecenter for renewable energies, Nov. 2000.

[6] GEXSI, "Global Market Study on Jatropha”, 2008

[7] GTZ, "Liquid Biofuels for Transportation: India country study on potential and implications for sustainable agriculture and energy.

[8] GTZ, “Jatropha in Madagaskar - Sachstandsbericht”, Dec. 2008.

[9] J. Uziak and I.A. Ukanov, "Performance Evaluation of Commonly used Oil Ram Press Machines", University of Botswana, Oct. 2007.

[10] K. Becker, B.Francis, "Die Jatropha Pflanze als Biodiesel-Lieferant in der Dritten Welt: Chancen fuer die Unternehmenskommunikation", Hohenheim, Germany.

[11] Peter Beerens and Jan de Jongh,'Note on Jatropha pressing for FACT pilot projects, FACT Foundation publication, May 2008.

[12] R.E.E. Jongschap, W.L. Corre, P.S. Bindraban \& W.A. Brandenburg, "Claims and Facts on Jatropha curcas L.”, Plant research international B.V. Wageningen, Okt. 2007.

[13] Reinhard K. Henning, “Das Jatropha System”, Weissensberg, Germany.

[14] Reinhard K. Henning, “ Identification, selection and multiplication of high yielding Jatropha curcas L. plants and economic key points for viable Jatropha oil production”, Sept. 2007. 
[15] Sharma Naveen, "Plantation Management; Activities/ Labour Costs", Bio-diesel Division, Ruchi Soya Industries, South tukoganj.

[16] T. Mendoza, O. Zamora, J. Lales, "Jatropha: What the public should know", Faculty of crop sciences, University of Philippines, Los Banos, Aug. 2007.

[17] Water and Energy Commission Secretariat, "Energy Synopsis Report 2006”, June 2006, Kathmandu.

[18] Winrock Int. Kathmandu," Using Community-Grown Jatropha Oil for Irrigation Pumps to Support Increase Agricultural Production and Rural Economic Growth", 2009. 